\title{
STUDI PENGARUH VARIASI KONSENTRASI GARAM TERHADAP CITARASA PEDA IKAN LAYANG (Decapterus russelli)
}

\author{
Rastuti W Paparang \\ Fakultas Perikanan dan Ilmu Kelautan, Universitas Sam Ratulangi, Manado, Sulawesi Utara.
}

\begin{abstract}
ABSTRAK
Tujuan dari penelitian ini adalah untuk mengetahui citarasa peda ikan layang (Decapterus russelli) yang diberi perlakuan variasi konsentrasi garam 10, 15 dan 20\%. Peda merupakan salah satu produk olahan ikan secara tradisional yang dibuat dengan cara penggaraman kemudian diikuti dengan cara fermentasi. Jenis ikan yang umum dibuat peda antara lain adalah ikan layang. Di Sulawesi Utara ikan ini dikenal dengan nama ikan malalugis dan memiliki potensi untuk dikembangkan karena jumlah produksinya yang cukup besar. Metode yang digunakan dalam penelitian ini bersifat eksperimental dan parameter yang dianalisis adalah kadar air, lemak, tekstur dan citarasa. Hasil yang diperoleh menunjukkan bahwa peda ikan layang dengan konsentrasi garam 20\% memiliki nilai kadar air yang lebih rendah serta citarasa yang lebih disukai.
\end{abstract}

Kata kunci: ikan layang, peda, citarasa.

\section{PENDAHULUAN}

Sifat ikan yang mudah busuk mengakibatkan ikan tidak dapat dikonsumsi dalam bentuk segar di tempat-tempat jauh dari tempat penangkapan ikan dan pendaratan ikan. Biasanya untuk memperpanjang masa simpan, teknik pengolahan dan pengawetan yang dilakukan masyarakat masih bersifat tradisional seperti pengasapan, pengeringan, penggaraman, dan fermentasi. Di Provinsi Sulawesi Utara produk olahan tradisional yang dihasilkan oleh nelayan atau pengolah hasil perikanan adalah ikan cakalang fufu (asap), roa fufu, ikan asin dan bakasang. Hasil olahan tersebut sebagian besar dikonsumsi lokal dan sebagian kecil diantar-pulaukan.

Peda merupakan salah satu produk olahan ikan secara tradisional yang dibuat dengan cara penggaraman kemudian diikuti dengan cara fermentasi. Jenis ikan yang umum dibuat peda antara lain adalah ikan kembung (Scomber sp.) dan ikan layang (Decapterus sp.). Ikan layang (Decapterus russelli) merupakan jenis ikan pelagis yang banyak terdapat di perairan Sulawesi Utara sehingga ikan ini mempunyai potensi yang baik untuk dikembangkan. Di Provinsi Sulawesi Utara ikan layang dikenal dengan nama malalugis dan memiliki jumlah produksi yang cukup besar, dimana pada tahun 2004 jumlah produksinya mencapai 44.721,6 ton (Anonimous, 2005).

Masyarakat nelayan Sulawesi Utara belum begitu kenal dengan produk peda, oleh sebab itu berdasarkan hal tersebut, penulis ingin meneliti tentang pengaruh variasi konsentrasi garam terhadap citarasa dari peda ikan layang.

\section{METODOLOGI PENELITIAN}

Metode yang digunakan dalam penelitian ini bersifat eksperimental. Menurut Mantjoro, dkk. (1990) metode eksperimental yaitu suatu bentuk penelitian yang digunakan dengan cara merubah suatu keadaan untuk melihat kejadian yang timbul akibat dari perubahan tersebut.

\section{Bahan dan Alat}

Bahan baku yang digunakan dalam penelitian ini adalah ikan layang (D. russelli) serta bahan tambahan berupa garam. Bahan kimia yang digunakan adalah petroleum eter, bahan penetral untuk uji organoleptik (tekstur dan citarasa) yaitu roti tawar dan air minum. Alat yang digunakan terdiri dari timbangan, alat pengering, pemberat, wadah plastik, cawan porselen, oven, desikator, blender, labu lemak dan alat ekstraksi soxhlet.

\section{Prosedur Penelitian}

Ikan layang (D. russelli) segar yang akan dibuat peda, dibuang sisik, insang dan isi perutnya, kemudian dicuci bersih dengan menggunakan air mengalir. Selanjutnya ikan yang telah bersih disusun dalam wadah untuk penggaraman, dimana cara penyusunannya bergantian antara lapisan garam dan lapisan 
ikan. Pada bagian bawah dan atas dari wadah diberi lapisan garam setebal $1-2 \mathrm{~cm}$, lalu wadah ditutup dan diberi pemberat. Proses penggaraman berlangsung selama seminggu, kemudian ikan dikeluarkan dari wadah dan dibersihkan dari garam yang menempel, lalu dijemur selama 3 jam. Selanjutnya ikan dimasukkan lagi ke dalam wadah yang pada alasnya diberi kertas, kemudian ditutup dengan rapat agar proses fermentasi berjalan dengan baik. Proses pembuatan peda dianggap selesai setelah tercium bau peda yang khas, dimana lamanya fermentasi minimal satu minggu. Kemudian peda dijemur kembali selama kurang lebih 6 jam agar proses fermentasi terhenti serta mendapatkan hasil peda yang kering dan awet.

\section{Prosedur Analisis}

Parameter yang dianalisis dalam penelitian ini yaitu kadar air, kadar lemak (Anonimous, 1981), tekstur dan citarasa (Soekarto, 1982).

\section{HASIL DAN PEMBAHASAN}

Data pengaruh perlakuan variasi konsentrasi garam terhadap rata-rata kadar air, lemak, tekstur dan citarasa peda ikan layang dapat dilihat pada Tabel 1 .

Tabel 1. Data pengaruh perlakuan variasi konsentrasi garam terhadap rata-rata kadar air, lemak, tekstur dan citarasa peda ikan layang.

\begin{tabular}{lccc}
\hline \multirow{2}{*}{ Parameter yang diukur } & \multicolumn{3}{c}{ Variasi Konsentrasi Garam } \\
\cline { 2 - 4 } & $\mathbf{1 0 \%}$ & $\mathbf{1 5 \%}$ & $\mathbf{2 0 \%}$ \\
\hline Kadar Air (\%) & 54,43 & 50,73 & 47,06 \\
Kadar Lemak (\%) & 4,76 & 4,57 & 4,51 \\
Tekstur & 6,54 & 6,27 & 5,94 \\
Citarasa & 6,30 & 6,54 & 7,20 \\
\hline
\end{tabular}

\section{Kadar Air}

Pengaruh perlakuan variasi konsentrasi garam terhadap kadar air peda, menunjukkan bahwa nilai rata-rata kadar air mengalami penurunan dengan bertambahnya konsentrasi garam yang diberikan yaitu $54,43 \%$ pada konsentrasi garam $10 \%, \quad 50,73 \%$ pada konsentrasi garam $15 \%$ dan $47,06 \%$ pada konsentrasi garam 20\%. Hubungan konsentrasi garam terhadap kadar air peda dapat dilihat pada Gambar 1. Menurunnya kadar air tersebut sesuai dengan pernyataan Desroiser (1988), bahwa semakin besar kadar garam yang diberikan maka semakin banyak air yang akan ditarik oleh ion garam. Selanjutnya Moeljanto (1982) menyatakan bahwa karena konsentrasi garam di luar tubuh ikan lebih pekat dari pada cairan di dalam tubuh ikan, maka garam akan merembes masuk ke dalam tubuh ikan, sedangkan air akan merembes keluar. Afrianto dan Liviawaty (1989) juga menyatakan bahwa semakin tinggi perbedaan konsentrasi antara garam dengan cairan yang terdapat di dalam tubuh ikan, maka semakin cepat proses penetrasi garam ke dalam tubuh ikan bersamaan dengan keluarnya cairan dari dalam tubuh ikan karena tekanan osmosa.

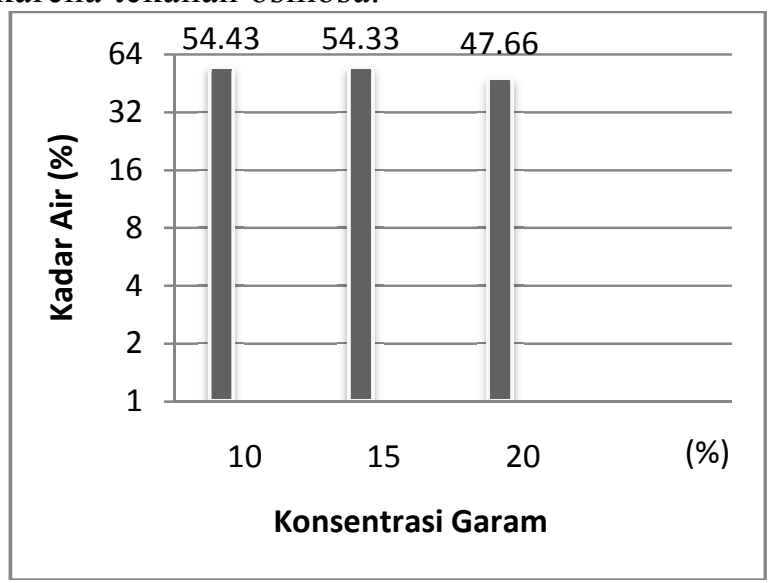

Gambar 1. Hubungan konsentrasi garam terhadap kadar air peda ikan layang.

\section{Kadar Lemak}

Berdasarkan hasil analisa ternyata kadar lemak peda mengalami penurunan dengan meningkatnya konsentrasi garam yang diberikan yaitu berturut-turut $4,76 \%$ pada konsentrasi garam $10 \%, \quad 4,57 \%$ pada konsentrasi garam $15 \%$, dan $4,51 \%$ pada konsentrasi garam 20\%. Hubungan konsentrasi garam yang diberikan terhadap kadar lemak dapat dilihat pada Gambar 2.

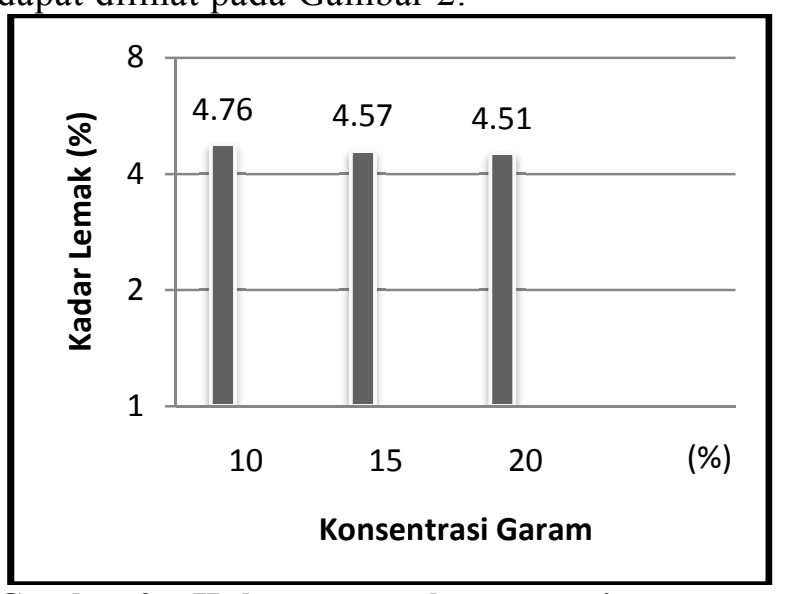

Gambar 2. Hubungan konsentrasi garam terhadap kadar lemak peda ikan layang. 
Menurut Hall (1992), penurunan kadar lemak yang disebabkan oleh pengaruh konsentrasi garam, terjadi karena garam dapat berperan sebagai katalis pada proses oksidasi dari lemak ikan. Winarno (1992) dan Ketaren (2005) juga menyatakan bahwa lemak dapat mudah rusak akibat adanya kandungan air dalam bahan pangan, sehingga lemak terhidrolis menjadi gliserol dan asam lemak bebas.

\section{Tekstur}

Perubahan nilai tekstur peda karena variasi konsentrasi garam dapat dilihat pada Gambar 3. Dari gambar tersebut terlihat adanya penurunan nilai tekstur dengan semakin tingginya konsentrasi garam. Nilai tertinggi terdapat pada konsentrasi garam $10 \%$ yaitu 6,34 dan nilai terendah pada konsentrasi garam $20 \%$ yaitu 6,14 .

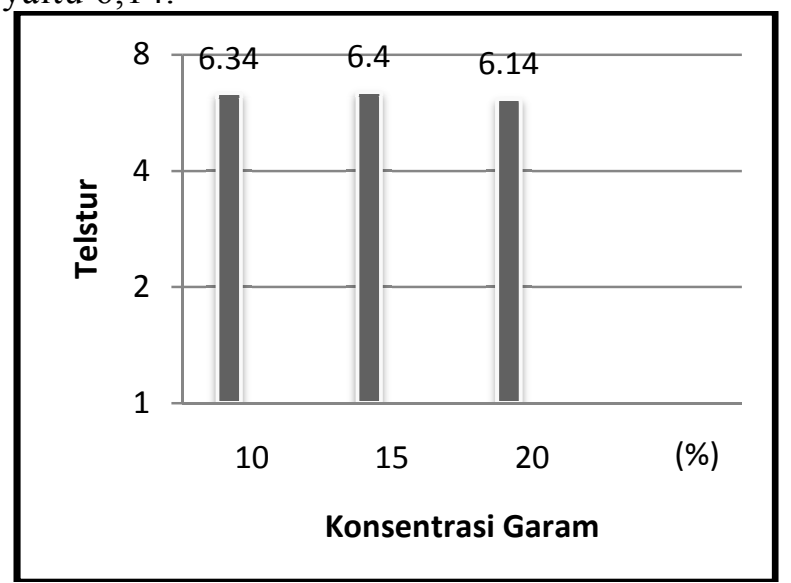

Gambar 3. Hubungan konsentrasi garam terhadap tekstur peda ikan layang.

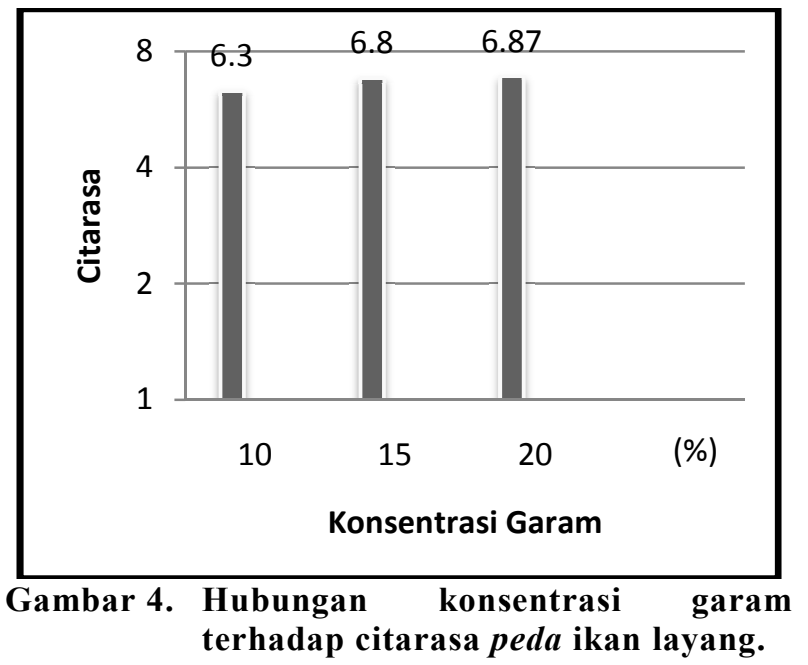

Adanya perubahan konsentrasi garam dalam fermentasi akan menyebabkan terjadinya penarikan air dari jaringan ikan yang menimbulkan berbagai perubahan fisik dan kimia, seperti tekstur (Adawyah, 2008).
Selanjutnya juga dikatakan bahwa konsistensi masir pada peda, sangat dipengaruhi oleh kandungan lemaknya dan juga oleh enzim protoelotik yang dalam aktivitasnya akan merubah tekstur ikan menjadi masir.

Menurut Moeljanto (1982) nilai tekstur juga dapat dipengaruhi oleh adanya ketidakmurnian garam yang dapat menyebabkan daging ikan menjadi keras, rapuh dan kaku.

\section{Citarasa}

Hasil analisa nilai citarasa peda menunjukkan bahwa semakin tinggi konsentrasi garam yang diberikan maka nilai citarasa semakin meningkat. Nilai tertinggi terdapat pada konsentrasi garam $20 \%$ yaitu 6,87 dan nilai terendah terdapat pada konsentrasi $10 \%$ yaitu 6,30. Hubungan konsentrasi garam terhadap nilai citarasa peda dapat dilihat pada Gambar 4. Pada konsentrasi garam 15 dan 20\% ternyata peda memiliki citarasa yang lebih disukai oleh panelis dibanding pada konsentrasi garam 10\%. Menurut Afrianto dan Liviawaty (1989) selama proses fermentasi berlangsung akan terbentuk asam propionat yang dapat memberikan rasa khas peda yang sangat disukai konsumen. Menurut Hall (1992) asam propianat dihasilkan dari lemak ikan yang mengalami autolisis selama berlangsungnya proses penggaraman. Diduga pada konsentrasi garam 15 dan $20 \%$ asam propianat yang terbentuk lebih banyak dibanding dengan konsentrasi garam $10 \%$.

\section{KESIMPULAN DAN SARAN}

Hasil penelitian menunjukkan bahwa peda ikan layang (Decapterus russelli) pada variasi konsentrasi garam 20\% memiliki kadar air yang lebih rendah serta citarasa yang lebih disukai dibandingkan dengan peda pada variasi konsentrasi garam 10 dan $15 \%$.

\section{DAFTAR PUSTAKA}

Adawyah, M.P., 2008. Pengolahan dan Pengawetan Ikan. PT. Bumi Aksara, Jakarta.

Afrianto, E., dan E. Liviawaty, 1989. Pengawetan dan Pengolahan Ikan. Kanisius, Yogyakarta.

Anonimous, 1981. Kumpulan Petunjuk Praktis Pengujian Kimia Hasil Perikanan. Direktorat Jenderal Perikanan, Departemen Pertanian, Jakarta.

Anonimous, 2005. Buku Tahunan Statistik Perikanan. Dinas perikanan Daerah Tingkat I, Provinsi Sulawesi Utara.

Desrosier, N.W., 1988. Teknologi Pengawetan Pangan. IU Press, Jakarta. 
Hall, G.M., 1992. Fish Processing Technology. VCH Publishers, Inc., New York.

Ketaren S., 2005. Minyak dan Lemak Pangan. UI Press, Jakarta.

Mantjoro, E., O. Pontoh, O. Manus, 1990. Pengantar Filsafat Ilmu. Fakultas Perikanan, Unsrat, Manado.

Moeljanto, R., 1982. Penggaraman dan Pengeringan Ikan. PT. Penebar Swadaya, Jakarta.
Soekarto, S.T., 1985. Penilaian Organileptik untuk Industri Pangan dan Hasil Pertanian. Bhratara Karya Aksara, Jakarta.

Winarno, F.G., 1992. Kimia Pangan dan Gizi. PT. Gramedia Pustaka Utama, Jakarta. 